\title{
PENGARUH CITRA PERBANKAN TERHADAP KEPUTUSAN NASABAH DALAM MENGAMBIL KREDIT DENGAN PELAYAN DAN PROSEDUR KREDIT SEBAGAI VARIABEL MODERATING PADA PD BPR BANK MAKASSAR
}

\author{
WIDYA ORINDA \\ Institut bisnis dan keuangan nitro makassar \\ Email: Widyaorinda2709@gmail.com
}

\section{ABSTRAK}

Penelitian ini bertujuan untuk mengetahui (1) Pengaruh Citra Perbankan terhadap Keputusan Nasabah dalam Mengambil Kredit pada PD BPR Makassar; (2) Pengaruh Citra Perbankan terhadap Keputusan Nasabah dalam Mengambil Kredit dengan Pelayanan sebagai Variabel Moderasi pada PD BPR Bank Makassar; (3) Pengaruh Citra Perbankan terhadap Kredit Keputusan Nasabah dalam Mengambil Kredit dengan Prosedur Kredit sebagai Variabel Moderasi pada PD BPR Bank Makassar.

Menurut Munandar (2015) (Kutipan dalam Daga,2021) Anggaran Pendapatan dan Belanja Negara (APBN) merupakan rencana keuangan tahunan pemerintahan negara Indonesia yang disetujui oleh Dewan Perwakilan Rakyat (DPR).

\section{PENDAHULUAN}

Bank adalah suatu badan usaha yang menghimpun dana dari masyarakat dalam bentuk simpanan dan menyalurkan ke masyarakat dalam bentuk kredit dan atau bentuk-bentuk lainnya dalam rangka meningkatkan taraf hidup rakyat banyak. 
Di antara kegiatan perbankan tersebut yang menjadi permasalahan dalam penilitan ini adalah mengenai kegiatan penyaluran kredit kepada masyarakat atau nasabah. Seberapa banyak masyarakat yang memutuskan mengambil kredit pada suatu bank akan memberikan pengaruh yang besar terhadap keuntungan suatu perbankan,karena laba yang didapati oleh suatu perbankan salah sutunya adalah dari suku bunga pengambilan kredit oleh para nasabah. Kemudian proses pengambilan kredit oleh seorang nasabah itu sendiri terjadi ketika seorang nasabah memutuskan untuk mengambil kredit merupakan salah satu proses yang ada dalam aktivitas perbankan, setelah mempertimbangkan kemudian memilih suatu alternatif dari beberapa alternatif yang ada. Adanya perbedaan jumlah nasabah yang memutuskan untuk mengambil kredit pada suatu bank di daerah.

Pada dasarnya bank perkreditan rakyat merupakan jenis bank yang beroperasi pada sektor kredit mikro sehingga segmentasi pasarnya adalah nasabah dengan kalangan masyarakat menengah ke bawah. Namun pada kenyataannya, saat ini keberadaan bank prekeditan rakyat semakin terdesak oleh keberadaan bank umum dan bank asing, sehingga bank nasabah dari kalangan menengah ke bawah atau menengah ke atas sama-sama lebih memilih mengambil kredit ke bank umum dan bank asing tersebut.

Bank umum dan bank asing tersebut memiliki modal yang lebih besar. Dengan adanya modal yang lebih besar tersebut, mereka mampu memberikan hadiah yang lebih spektakuler seperti mobil bagi nasabah yang beruintung, guna menarik perhatian nasabah serta sebagai sarana pemasaran perbankan. Bank umum dan bank asing dengan modalnya yang lebih besar juga dapat melakukan berbagai 
strategi pemasaran seperti memberikan fasilitas perbankan yang memadai dan pelayanan eksklusif misalnya pelayanan oleh seorang satpam yang berdiri di depan pintu kemudian memberikan ucapan selamat datan dan membrikan penjelasan mengenai cara berinteraksi cara tersebut dilakukan agar bank tersebut dapat dinilai menjadi bank yang besar serta terpecaya. Dengan begitu masyarakat terkadang cenderung memilih untuk bertransaksi kepada bank yang lebih memiliki nama besar atau citra perbankan yang baik, karena dinilai bank dengan citra yang baik akan lebih memuaskan nasabah. Penelitian.Hal ini memperkuat dugaan penulis jika nasabah dimakassar lebih memilih menggunakan jasa perbankan pada bank yang lebih memiliki nama besar karena dipengaruhi oleh adanya citra suatu bank.

Dari pengamatan penulis dan wawancara dengan salah satu karyawan di PD BPR Bank Makassar tingkat keramaian nasabah yang berdatangan pada bank-bank di makassar dapat dikatakan bahwa jumlah nasabah pada PD BPR Bank Makassar lebih sedikit dibandingkan bankbank disekitarnya yang memang memiliki citra dan nama besar yaitu Bank Mandiri, Bank BTN, Bank BNI, Bank BCA dan Bank BPD. Kondisi inilah yang menjadi salah satu permasalahan pada PD BPR Bank Makassar, karena saat ini di Makassar bank umum yang memiliki nama besar kini semakin banyak. Letak bank-bank tersebut yang berdekatan, membuat persaingan di antara mereka semakin ketat, sehingga kemungkinan pengaruh citra perbankan juga berpengaruh terhadap pemilihan nasabah dalam mengambil kredit di antara bankbank tersebut. Dengan demikian, PD BPR Bank Makassar harus benar-benar siap dalam menghadapi persaingan tersebut melalui beberapa usaha salah satunya dalam hal strategi pemasaran yang mantap guna menarik nasabah khususnya 
mengambil sektor kredit mikro yang memang pada dasarnya adalah pasar dari keberadaan Bank Perkreditan Rakyat di suatu daerah. Penelitian terdahulu yang telah dilakukan oleh Fatin Fitra Amalia pada tahun 2014 di Bank Makassar menunjukkan bahwa terdapat pengaruh positif dan signifikan antara Pelayanan dan Prosedur terhadap Keputusan Pengambilan Kredit. Hal ini menunjukkan kualitas sistem pelayanan dari suatu bank juga pantas menjadi pertimbangan bagi nasabah karena nasabah juga mencari kenyamanan saat bertransaksi. Kualitas pelayanan di PD BPR Bank Makassar sampai saat ini tidak mengalami banyak masalah, hanya saja ada beberapa pelanggan/nasabah yang penulis temui di PD BPR Bank Makassar yang merasa masih kurang pelayanannya. Salah satu faktor yang mungkin mempengaruhi keputusan nasabah dalam mengambil kredit pada PD BPR Bank Makassar sedikit adalah kurang optimalnya kualitas pelayanan dari bank seperti pelayanannya yang terbilang kurang cepat dan tempat duduk ruang tunggu yang kurang. Walaupun tergolong masyarakat menengah ke bawah, namun mereka juga ingin dihargai dan dilayani dengan istimewa. Hal itu penting dipertimbangkan karena masyarakat menengah ke bawah itulah yang merupakan pangsa pasar dari PD BPR Bank Makassar tersebut.faktor pelayanan yang diberikan oleh pihak bank menjadi salah satu variabel penelitian moderating yang memperkuat atau memperlemah pengaruh antara citra perbankan dengan keputusan nasabah dalam mengambil kredit.

Faktor berikutnya yang mempengaruhi hubungan antara citra perbankan dan keputusan nasabah dalam mengambil kredit adalah prosedur kredit yang diterapkan oleh pihak bank. Penelitian terdahulu yang dilakukan oleh Dedi Wahyu Nugroho 
tahun 2012 pada Bank BPR Makassar menunjukkan bahwa terdapat pengaruh positif dan signifikan antara Pelayanan dan Prosedur terhadap Keputusan Pengambilan Kredit. Prosedur kredit yang berbelit-belit, terlalu lama dan kurang konsisten akan lebih menyita waktu sehingga nasabah akan memilih bank yang memiliki sistem pelayanan yang praktis, cepat, tepat serta konsisten. Masyarakat Bone yang mayoritas merupakan masyarakat pedesaan, menyebabkan kepahaman mereka terhadap suatu prosedur-prosedur kredit masih minim. Prosedur kredit yang dinilai mudah, dapat dipahami dan cepat meski dengan suku bunga yang sedikit mahal, kemungkinan akan tetap berpengaruh positif terhadap minat nasabah dalam mengambil kredit pada suatu perbankan.

Dalam rangka mematangkan strategi pemasaran pada Bank Perkreditan Rakyat khususnya PD BPR Bank Makassar agar dapat mengikuti persaingan yang ada, maka perlu adanya suatu penelitian. Penelitian tersebut penting untuk mengetahui sejauh mana pengaruh 6 faktor-faktor yang telah dijelaskan tersebut dalam mempengaruhi keputusan nasabah untuk menggunakan jasa suatu bank khususnya khususnya transaksi pengambilan kredit pada PD BPR Bank Makassar. Berkaitan dengan hal itu maka penulis bermaksud membuat skripsi yang membahas mengenai "Pengaruh Citra Perbankan terhadap Keputusan Nasabah dalam Mengambil Kredit dengan Pelayanan dan Prosedur Kredit sebagai Variabel Moderating pada PD BPR Bank makassar”.

\section{TINJAUAN PUSTAKA}

1. Keputusan Nasabah dalam Mengambil Kredit

a. Pengertian Keputusan Nasabah dalam Mengambil Kredit 
Menurut Philip Kotler (2002: 207) Keputusan Nasabah dalam Mengambil Kredit merupakan sebuah proses keputusan mengambil kredit pada suatu bank. Menurut Griffin (2002) Keputusan Nasabah dalam Mengambil Kredit adalah suatu tindakan memilih satu alternatif dari serangkaian alternatif yang ada. Menurut Schiffman, Kanuk (2004, pada Kuncoro \& Adhitya 2010) Keputusan Nasabah dalam Mengambil Kredit adalah pemilihan dari dua atau lebih alternatif pilihan keputusan pengambilan kredit, artinya bahwa seseorang dapat membuat keputusan harus tersedia alternatif lainnya. Keputusan Nasabah dalam Mengambil Kredit adalah suatu proses pemilihan satu dari dua atau lebih alternatif pilihan keputusan pengambilan kredit setelah mempertimbangkan faktor-faktor yang mempengaruhinya.

Keputusan Nasabah dalam Mengambil Kredit sangat penting. Keputusan tersebut bermaksud agar tidak adanya hambatan dan kerja organisasi dapat sesuai dengan tujuan yang direncanakan sebelumnya, sehingga perlu diambil suatu 11 keputusan yang matang karena keputusan yang diambil dapat menimbulkan efek-efek tertentu. Menurut Samarwan (2004, pada Kuncoro \& Adithya, 2010) suatu keputusan merupakan sebagai pemilihan suatu tindakan dari dua atau lebih pilihan alternatif. Dengan demikian, ia harus mengambil keputusan produk apa yang akan dipilihnya, atau ia harus memilih satu dari beberapa pilihan produk kredit yang ada.

Keputusan Nasabah dalam Mengambil Kredit itu penting sebelum nasabah memutuskan untuk mengambil kredit. Agar tidak ada hambatan- 
hambatan yang mengganggu dan sesuai dengan apa yang diharapkan oleh nasabah.

b. Faktor-faktor yang mempengaruhi Keputusan Nasabah dalam Mengambil Kredit (Kotler, 2005: 211) :

1) Faktor Internal

a) Faktor pribadi merupakan salah satu faktor yang mempengaruhi keputusan nasabah. Karakteristik ini meliputi usia dan tahap siklus hidup, pekerjaan, situasi ekonomi, gaya hidup serta pendapatan. Orang akan mengambil atau tidak suatu kredit akan disesuaikan dengan keadaan yang terus berubah. Pekerjaan dan lingkungan ekonomi, juga mempengaruhi seseorang dalam mengambil kredit di suatu bank. Gaya hidup menggambarkan keseluruhan diri seseorang yang berinteraksi dengan lingkungannya, sedangkan kepribadian dan konsep diri dapat diartikan sebagai karakter psikologis yang berbeda dari seseorang yang menyebabkan tanggapan yang relatif konsisten dan bertahan lama terhadap lingkungannya.

b) Faktor psikologis dimana variabel psikologis ini dapat dibedakan menjadi motivasi, persepsi, pembelajaran, keyakinan dan sikap. Motivasi diartikan suatu kebutuhan yang akan berubah menjadi motif apabila kebutuhan itu telah mencapai tingkat tertentu. Motif adalah suatu kebutuhan yang cukup mendesak dan menekan seseorang untuk mengejar kepuasan. Persepsi adalah proses yang digunakan oleh seseorang individu untuk memilih, mengorganisasikan dan menginterpretasikan masukanmasukan yang 
diterimanya. Kondisi psikologis seseorang dapat mempengaruhi seseorang dalam mengambil sebuah keputusan seperti dalam mengambil sebuah kredit. Sebagai contoh seseorang sedang membutuhkan uang atau barang maka ia akan cenderung berusaha untuk memenuhinya dan salah satu jalan yang diambil adalah dengan mengambil kredit pada lembaga keuangan tertentu.

\section{2) Faktor Eksternal}

a) Faktor sosial adalah faktor lingkungan sekitar nasabah yang terdiri dari kelompok rujukan dan keluarga. Rekan kerja, 13 teman dan tetangga dapat dikategorikan menjadi kelompok rujukan baik secara langsung maupun tidak langsung dapat mempengaruhi keputusan nasabah. Keluarga merupakan organisasi nasabah atau konsumen yang paling penting dalam masyarakat dan para anggota keluarga menjadi kelompok acuan primer yang paling berpengaruh. Keluarga terdiri atas orang tua dan anak-anak yang memiliki pengaruh dalam pengambilan keputusan kredit yang ditawarkan oleh suatu bank atau lembaga keuangan lainnya.

b) Faktor Citra Perbankan, Pelayanan dan Prosedur Kredit dari bank atau lembaga keuangan yang menawarkan kredit bagi nasabah. Kottler (2003) yang menyebutkan bahwa citra perusahaan menggambarkan sekumpulan kesan (impressions), kepercayaan (beliefs) dan sikap (attitudes), yang ada di dalam benak konsumen terhadap perusahaan dalam pembentukan citra perusahaan terdapat beberapa indikator yang dijadikan ukuran dalam penilaian citra, yaitu kesan dan kepercayaan. Citra perbankan yang baik, 
akan mendorong nasabah memilih bank yang ia percaya untuk melakukan transaksi seperti mengambil kredit. Menurut Boediono, (1999: 11) yang dimaksud dengan pelayanan pelanggan (customer service) adalah upaya atau proses secara sadar dan terencana yang dilakukan organisasi atau badan usaha dalam persaingan melalui pemberian pelayanan kepada nasabah, sehingga tercapai kepuasan optimal bagi nasabah. Pelayanan yang baik dan prima disertai dengan sarana dan prasarana yang mendukung akan menarik nasabah untuk terus datang guna melakukan transaksi serta akan menjadi salah satu faktor yang akan mendorong calon nasabah lainnya. Menurut Malayu S.P. Hasibuan (2006) Prosedur kredit adalah suatu tahapantahapan yang harus dipenuhi oleh nasabah dalam penyaluran kredit. Prosedur kredit yang diterapkan akan berpengaruh terhadap kepuasan nasabah dalam mengambil kredit. Prosedur kredit yang mudah akan mendorong nasabah untuk mengambil kredit yang ditawarkan oleh suatu bank Pemikiran mengenai faktor-faktor yang mempengaruhi Keputusan Nasabah dalam Mengambil Kredit itu perlu diperhatikan, karena orang yang mengambil atau tidaknya suatu kredit akan disesuaikan dengan pendapatan pekerjaan dan lingkungan ekonomi seseorang yang akan mengambil kredit di suatu bank.

c. Cara mengukur Keputusan Nasabah dalam Mengambil Kredit 1) Pengenalan kebutuhan.

Merupakan suatu bahan pertimbangan dari seorang nasabah ketika ingin memutuskan untuk mengambil kredit apakah kredit yang dipilih 
memang sesuai dengan kebutuhan yang dibutuhkan oleh nasabah itu sendiri ataukah tidak.

2) Pencairan.

Seorang nasabah yang ingin mengambil kredit tentunya dengan segera ingin membutuhkan dana untuk digunakan selanjutnya. Maka dari itu seberapa lama pencairan dana dan seberapa mudah pencairan dana turut mempengaruhi keputusan nasabah untuk mengambil kredit pada suatu perbankan.

3) Informasi berbagai alternatif.

Berbagai informasi mengenai proses perkreditan yang ada juga akan mempengaruhi keputusan nasabah dalam mengambil kredit, karena informasi-informasi persuasif dan penyampaian informasi yang memadai akan semakin memudahkan nasabah dalam memilih kredit yang akan dipilih.

4) Keputusan mengambil kredit

Seberapa banyak jumlah nasabah yang memutuskan untuk mengambil kredit pada suatu bank, hal tersebut dapat dijadikan pengukuran bahwa pengukuran mengenai pengambilan kredit oleh nasabah adalah positif

5) Perilaku pasca mengambil kredit

Kemudian pengukuran terakhir dari keputusan nasabah dalam mengambil kredit adalah mengenai bagaimana perilaku pasca mengambil kredit nasabah tersebut. Apabila nasabah berinisiatif untuk mengambil kredit 
kembali pada bank yang sama, maka pengukuran mengenai pengambilan kredit oleh nasabah adalah positif (Kolter \& Amstrong, 2001: 222).

Cara mengukur Keputusan Nasabah dalam Mengambil Kredit diperlukan pengenalan kebutuhan sebelum mengambil kredit, dengan mencari berbagai informasi tentang kredit, agar pasca pengambilan kredit lancar sesuai apa yang diharapkan.

d. Indikator Keputusan Nasabah dalam Mengambil Kredit.

1) Persepsi melihat kinerja / performance karyawan.

Mengenai bagaimana kinerja karyawan apakah karyawan bekerja dengan benar dan sesuai prosedur ataukah banyak kesalahan yang dilakukan oleh seorang karyawan, sehingga mengganggu proses pengambilan kredit pada suatu bank.

2) Kepuasan akan kredit yang ditawarkan.

Penawaran kredit yang sesuai dengan kebutuhan masyarakat akan memberikan kepuasan bagi masyarakat yang memutuskan untuk mengambil kredit pada suatu bank.

3) Penyediaan informasi pada saat diterima.

Kemampuan perbankan dalam menyampaikan informasi yang baik ketika proses pengambilan kredit akan memudahkan nasabah dalam proses pengambilan kredit sehingga proses kredit yang dilakukan sesuai dengan yang diharapkan. 
4) Kepercayaan akan nama dan citra bank

Nama baik dan citra yang dimiliki oleh suatu bank akan memberikan pengaruh terhadap kepercayaan nasabah untuk memutuskan mengambil kredit pada bank yang diyakininya.

5) Pertimbangan pelayanan

Pelayanan prima yang diberikan oleh bank, akan mempengaruhi nasabah untuk memutuskan pengambilan kredit pada bank tersebut dikemudian hari (Kolter \& Amstrong, 2008). Keputusan Nasabah dalam Mengambil Kredit adalah suatu tindakan seseorang yang hendak melakukan kredit terhadap suatu bank, apakah menerima atau menolaknya.

\section{Citra Perbankan}

\section{a. Pengertian Citra Perbankan}

1) Pengertian Citra

Kotler menjelaskan bahwa "corporate image is the consumer's response to the total offering and is defined as a sum the belief, ideas, and impressions that a public has an organization." Citra perusahaan adalah respon konsumen pada 18 keseluruhan penawaran yang diberikan perusahaan dan didefinisikan sebagai sejumlah kepercayaan, ide-ide, dan kesan masyarakat pada suatu organisasi. Nguyen dan Leblanc mengungkapkan citra perusahaan sebagai berikut : 
"Corporate image is described as overall impression made on the minds of the public about organization. It is related to business name, architecture, variety of product/services, tradition, ideology, an to the impression of quality commuicated by each employee interacting with the organization's clients". Citra perusahaan merupakan keseluruhan kesan yang terbentuk di benak masyarakat tentang perusahaan. Dimana citra tersebut berhubungan dengan nama bisnis, arsitektur, variasi dari produk, tradisi, ideologi dan kesan pada kualitas komunikasi yang dilakukan oleh setiap karyawan yang berinteraksi dengan klien organisasi. Sementara Dowling menyatakan bahwa "corporate image is a set of beliefs and feeling about an organizations“, yang artinya citra perusahaan merupakan sekumpulan kepercayaan dan perasaan-perasaan tentan suatu organisasi. (http://oeconomicus.files.wordpress.com/2007/07/citraperusahaan. pdf, diakses pada tanggal 20 Mei 2014). Menurut Iman (2007) citra perusahaan tidak bisa direkayasa, artinya citra tidak datang dengan sendirinya melainkan dibentuk oleh masyarakat dari upaya komunikasi dan keterbukaan perusahaan dalam usaha membangun citra positif yang diharapkan.

Upaya membangun citra tidak bisa dilakukan secara serampangan pada saat tertentu saja, tetapi merupakan suatu proses yang panjang karena citra merupakan semua persepsi atas objek yang dibentuk oleh konsumen dengan cara memproses informasi dari berbagai sumber sepanjang waktu

2) Pengertian Bank
a) Pengertian Bank 
Bank adalah lembaga perantara keuangan atau pihak-pihak yang memiliki kelebihan dana dengan pihak-pihak yang membutuhkan dana, serta berfungsi memperlancar lalu lintas pembayaran dengan berpihak pada falsafah kepercayaan (Taswan, 2005: 2). Menurut Undang-Undang Nomor 10 ayat (2) tahun 1998: bank adalah badan usaha yang menghimpun dana dari masyarakat dalam bentuk simpanan dan menyalurkan ke masyarakat dalam bentuk kredit dan atau bentuk-bentuk lainnya dalam rangka meningkatkan taraf hidup rakyat banyak. Peran bank sebagai lembaga keuangan juga dinyatakan dalam PSAK No. 31 bahwa bank adalah: suatu lembaga yang berperan sebagai perantara keuangan (financial intermediary) antara pihak yang memiliki kelebihan dana (surplus unit) dan pihak yang memerlukan dana (deficit unit), serta sebagai lembaga yang berfungsi memperlancar lalu lintas pembayaran. (Ikatan Akuntan Indonesia, 2007: 31.1).

b) Fungsi Bank

Menurut Mudrajad Kuncoro (2002), bank memiliki fungsi sebagai berikut:

(1) Menghimpun dana dari masyarakat dalam bentuk simpanan. Kegiatan ini merupakan kegiatan membeli dana dari masyrakat yang biasanya disebut dengan funding. Kegiatan ini dilakukan dengan cara menawarkan berbagai jenis simpanan, misalnya simpanan giro, simpanan tabungan, dan simpanan deposito. 
(2) Menyalurkan dana untuk masyarakat dalam bentuk kredit. Kegiatan ini dikenal dengan kegiatan lending. Kredit- kredit yang biasa ditawarkan misalnya kredit investasi, kredit modal kerja, kredit perdagangan, dan lainlain.

(3) Memberikan jasa-jasa lainnya untuk mendukung kelancaran transaksi kegiatan menghimpun dan menyalurkan dana. Jasa-jasa bank yang sering ditawarkan misalnya kiriman uang (transfer), kliring, inkaso, dan kartu kredit.

a. Jenis-jenis Bank

Perbedaan jenis perbankan menurut Thomas (2003) dapat

dilihat dari beberapa segi, yaitu:

1) Dilihat dari segi fungsinya

(a) Bank Sentral (Central Bank) adalah bank yang bertanggungjawab atas kebijakan moneter di wilayah negara tersebut. Bank Sentral berusaha untuk menjaga stabilitas nilai mata uang, stabilitas sektor perbankan, dan sistem finansial secara keseluruhan.

(b) Bank Umum (Commercial Bank) adalah bank yang dalam mengumpulkan dana dengan menerima simpanan dalam netuk giro dan deposito dan dalam usahanya terutama memberikan kredit dalam jangka pendek.

(c) Bank Tabungan (Saving Bank) adalah bank yang dalam mengumpulkan dananya menerima simpanan dalam bentuk tabungan dan dalam usahanya terutama memperbungakan dananya dalam kertas berharga. 
(d) Bank Pembangunan (Development Bank) adalah bank yang dalam mengumpulkan dananaya terutama menerima simpanan dalam bentuk deposito dan atau mengeluarkan kertas berharga jangka menengah dan panjang, serta dalam usahanya terutama memberikan kredit jangka menengah dan panjang di bidang pembangunan.

(e) Bank Desa (Rural Bank) adalah bank yang menerima simpanan dalam bentuk uang dan natural dan dalam usahanya memberikan kredit jangka pendek dalam bentuk uang maupun dalam bentuk natura kepada sektor pertanian dan pedesaan.

2) Dilihat dari segi kepemilikannya

(a) Bank milik pemerintah, yaitu bank yang akte pendiriannya maupun modal sepenuhnya dimiliki pemerintah Indonesia.

(b) Bank milik swasta nasional, yaitu bank yang sebagian besar atau seluruh saham dan akte pendiriannya dimiliki oleh swasta nasional.

(c) Bank milik koperasi, yaitu bank yang saham- sahamnya dimiliki oleh perusahaan yang berbadan hukum koperasi.

(d) Bank milik asing, yaitu bank yang merupakan cabang dari bank yang ada di luar negeri, baik milik swasta asing atau pemerintah asing.

(e) Bank milik campuran, yaitu bank yang memiliki oleh pihak asing dan pihak swasta nasional.

(3) Dilihat dari segi status 
(a) Bank devisa, yaitu bank yang dapat melaksanakan transaksi keluar negeri atau yang berhubungan dengan mata uang asing secara keseluruhan.

(b) Bank non devisa, yaitu bank yang belum mempunyai izin untuk melakukan transaksi sebagai bank devisa. Dilihat dari segi cara menentukan harga

(a) Bank yang berdasarkan prinsip konvensional.

(b) Bank yang berdasarkan prinsip syariah.

(4) Bank adalah suatu badan usaha yang memiliki wewenang dan fungsi menghimpun dana masyarakat untuk disalurkan kembali kepada pihak yang memerlukan dana.

3) Pengertian Citra Perbankan

Citra Perbankan adalah respon masyarakat terhadap perbankan yang diwujudkan dalam ide atau keyakinan masyarakat terhadap produk yang ditawarkan oleh perbankan tersebut. Dengan memperhatikan nama baik

\section{METODOLOGI PENELITIAN}

\section{A. DEFINISI OPERASIONAL VARIABEL}

1. Variabel terikat / dependent variable ( $Y$ )

Variabel dependen (variabel $Y$ ) atau variabel terikat, yaitu suatu variabel yang dipengaruhi atau menjadi akibat adanya variabel bebas. Dalam penelitian ini yang menjadi variabel $\mathrm{Y}$ (variabel dependen) yaitu Keputusan Nasabah dalam Mengambil Kredit. Keputusan Nasabah dalam Mengambil Kredit adalah suatu 
proses yang dilakukan nasabah pada saat mengambil kredit, kemudian nasabah memilih satu alternatif dari alternatif yang ada. Setelah membandingkan produkproduk kredit yang dimiliki oleh beberapa perbankan lainnya, maka muncul inisiatif nasabah untuk memilih diantara produk kredit tersebut sesuai dengan keinginan dan kebutuhan nasabah itu sendiri.

2. Variabel bebas / independent variable $(X)$

Variabel independen (variabel $\mathrm{X}$ ) atau variabel bebas adalah variabel yang mempengaruhi dan merupakan faktor penyebab yang mempengaruhi variabelvaribel lainnya. Variabel bebas dalam penelitian ini yaitu Citra Perbankan. Citra Perbankan adalah respon masyarakat terhadap perbankan yang diwujudkan dalam ide atau keyakinan masyarakat terhadap produk yang ditawarkan oleh perbankan tersebut.

3. Variabel Moderasi / Moderat Variable ( Z )

Variabel moderasi (variabel Z) adalah varibel yang secara teoritis dapat mempengaruhi (memperkuat atau memperlemah) hubungan antara variabel independen dengan variabel dependen (Sugiyono, 2012: 60). Dalam penelitian ini terdapat dua variabel moderasi, yaitu:

a. Pelayanan ( Z1)

Pelayanan adalah upaya atau proses secara sadar dan terencana dilakukan organisasi atau badan usaha kredit dalam memenangkan persaingan melalui pemberian/perjanjian pelayanan kepada nasabah, sehingga tercapai kepuasan optimal bagi nasabah.

b. Prosedur Kredit (Z2) 
Prosedur Kredit adalah upaya bank dalam mengurangi resiko pemberian kredit, yang dimulai dengan tahapan penyusunan perencanaan pengkreditan, dilanjutkan dengan proses pemberian keputusan kredit (prakarsa, analisis dan evaluasi, negoisasi, rekomendasi dan pemberian keputusan kredit), penyusunan pemberian kredit, dokumentasi dan administrasi kredit, persetujuan pencairan kredit serta pengawasan dan pembinaan kredit.

\section{B. ANALISIS DATA}

Pengolahan dan analisis data penelitian dilakukan dengan menggunakan software SPSS (Statistical Product and Service Solutions) 16.0 for Windows, sedangkan untuk memecahkan permasalahan pokok yang dihadapi oleh perusahaan, maka digunakan metode analisis sebagai berikut :

1. Uji Prasyarat Analisis

a. Uji Normalitas

Uji normalitas merupakan uji yang dilakukan untuk mengetahui apakah variabelvariabel dalam penelitian

Sumber : Data primer yang diolah

memiliki sebaran distribusi normal atau tidak. Uji ini perlu dilakukan karena semua perhitungan statistik parametrik memiliki asumsi normalitas sebaran. Model regresi yang baik adalah memiliki distribusi data normal atau mendekati normal (Ghozali, 2006).

b. Uji Linearitas 
Uji linearitas merupakan uji yang digunakan untuk mengetahui apakah variabel bebas dan terikat dalam penelitian memiliki hubungan yang linear, serta untuk melihat apakah spesifikasi model yang digunakan dalam penelitian ini sudah benar atau tidak. Uji linear perlu dilakukan karena korelasi produk momen dan turunannya mengasumsikan hubungan antar variabelnya bersifat linear.

\section{Daftar Pustaka}

Afnil Guza. (2008). Himpunan Undang-Undang Perbankan Republik Indonesia. Jakarta: Asa Mandiri.

Basu Swastha dan Ibnu Sukotjo. (2007). Pengantar Bisnis Modern. Yogyakarta: Liberty Yogyakarta.

Boediono. (1999). Pelayanan Prima. Jakarta: Yayasan Kawita Indonesia.

David H. Bangs, Jr. (2001). Pedoman Menyusun Rencana Pemasaran, The Market Planning Guige. Jakarta: Erlangga.

Dedi Wahyu Nugroho. (2012). "Pengaruh Lokasi, Pelayanan dan Prosedur Kredit Terhadap Keputusan Nasabah dalam Mengambil Kredit pada PD.BPR Boyolali”. Yogyakarta : Skripsi. Universitas Negeri Yogyakarta

Deviana Rahmasari. (2012). "Pengaruh Penerapan Corporate Social Responsibilty terhadap loyalitas Nasabah dengan Citra Perbankan dan Sikap Nasabah sebagai

Variabel Intervening". Yogyakarta: Skripsi. Universitas Negeri Yogyakarta

Evy Kartikasari. (2008). "Pengaruh Citra Perusahaan, Nilai yang dirasa dan Kepuasan terhadap Loyalitas Nasabah pada Industri Perbankan". Surabaya : Skripsi. Sekolah Tinggi Ilmu Ekonomi Perbanas Surabaya

Fatin Fitra Amalia. (2014). "Pengaruh Gaji, Suku Bunga, Pelayanan, Dan Prosedur Terhadap Keputusan Pengambilan Kredit Pada Nasabah Bank Jateng Cabang Kudus". Kudus : Skripsi. Universitas Muria Kudus 
Hasibuan, Malayu S.P. (2005). Manajemen Sumber Daya Manusia. Jakarta : Bumi Aksara.

Iman Mulyana. (2007). Citra Perusahaan [Online]. Tersedia: http:

//oeconomicus.files.wordpress.com/2007/07/citraperusahaan.pdf.ht ml [20 Mei 2014].

Kotler, Philip. (2005). Manajemen Pemasaran Edisi Milenium. Jakarta: Pearson Education Asia Pte. Ltd dan PT. Prenhallindo.

Daga, R., \& Renaldy, R. (2019). Faktor yang mempengaruhi terjadinya retur surat perintah pencairan dana (Studi Kasus Pada Kantor Pelayanan Perbendaharaan Negara Makassar I). Jurnal Mirai Management, 4(2), 243-262. 